\title{
Normalizing of estrous cycle in polycystic ovary syndrome (PCOS) induced rats with Tephrosia purpurea (Linn.) Pers.
}

\author{
Akanksha P. Thakor* and Anuradha J. Patel ${ }^{1}$ \\ Department of Biotechnology, N. B. Mehta Science College, Bordi-401701, INDIA \\ ${ }^{1}$ Department of Zoology, Bhavans College, Andheri, Mumbai, INDIA \\ *Corresponding author. E-mail: akii.dev@gmail.com \\ Received: August 2, 2013; Revised received: April 26, 2014; Accepted: May 5, 2014
}

\begin{abstract}
This study evaluates the potentiality of an herbal plant Tephrosia purpurea (Linn.) Pers. in the treatment of Letrozole induced polycystic ovary syndrome (PCOS) using female Albino wistar rats. Seed powder of $T$. purpurea at concentration of $200 \mathrm{mg} / \mathrm{kg}$ body weight with milk as a carrier vehicle $3 \mathrm{ml} / \mathrm{kg}$ body weight, given for at least 3 consecutive estrous cycles. Vaginal smear, FSH, LH, Testosterone, and Estrogen were analyzed to determine the fluctuations in sex steroid level in PCOS induced rats. The plasma testosterone and estrogen level were found to be significantly increased in rats with PCOS whereas Follicle stimulating hormone and Leutinizing hormone did not show any changes. When compared with control the PCOS induced rats showed characteristic ovary with high incidence of ovarian cyst. All the parameters assessed were significantly improved after the treatment with T. purpurea and achieved level close to $80 \%$ normalcy. Effect of $T$. purpurea significantly reduced histopathological changes in ovary and endocrinological and biochemical changes induced by hyperandrogenism. Further to check ovulation and fertility female rats were mated and pregnancy was confirmed. Thus potential of T. purpurea in the treatment of PCOS using an animal model suggested being a good alternative therapy in the treatment of PCOS.
\end{abstract}

Keywords: Carboxymethylecellulose, Estrogen, Estrous cycle, Letrozole, Polycystic ovary syndrome, Testosterone, Tephrosia purpurea

\section{INTRODUCTION}

Polycystic ovary syndrome (PCOS) is an endocrine disorder characterized by anovulation, amenorrhea, hirsutism and infertility. It is also known as stein Levithel syndrome (Shearman, 1985; Speroff et al., 1999; Fallon, 2006). PCOS is the most common disorder in women of reproductive age group as well as premenopausal women (Janssen et al., 2004; Zarger et al., 2005). PCOS treatment is directed to the ovary for normalizing its functions. Medications are used to regulate the menstrual cycles to stimulate ovulation and normalize hormonal level. As different drugs used in treatment of PCOS cater to different symptoms, effective treatment to manage PCOS is a challenge. In spite of tremendous progress in the development of modern medicine, plants continue to be an important source of drug for the treatment of several diseases and hence demands for plant drug have increased (Pandey et al., 2003). To a large worldly population, medicinal plants are the only source to prevent and treat various diseases. Herbal product such as Ashwagandha, Mimosa, Aloe vera etc. has been used by some researchers (Craig, 1999).

Herbal plant drug form main source of health care due to more effectiveness, lower cost and well tolerated by the patient having fewer unintended consequences and fewer side effects than traditional medicine and may be safer to use. Herbal plants have been used since centuries to correct disorders caused by the hormonal imbalance related to female reproductive system (Nadkarni, 1982; Shearman, 1985; Khare, 2004). Tephrosia purpurea (Linn) Pers. is a wild plant known as Sarapunkha in Sanskrit, Purple Tephrosia or wild indigo in English and Aurvi or Kolinji in Tamil (Nadkarni, 1982). T. purpurea has been used for centuries in Indian traditional medicine. This plant found in Bordi, Aswali region and it is used by the tribal community for treating female reproductive disorder, dog bite, as a fodder of cattle and various inflammatory disorders. It is beneficial for liver spleen and kidney disorder (Deshpande et al., 1968; Saleem et al., 1999). Also it has the property to address recovery from different wounds. (Hans et al., 2000; Joshi and Oleacea, 2000) and there is no scientific report on effect of seed powder of $T$. purpurea on chemically induced (Letrozole) PCOS in Albino Wistar rats. Keeping this in view, the present study was designed to evaluate the effect of seed powder of $T$. purpurea along with milk in modifying, letrozole induced PCOS in rat. 
Table 1. Comparison of estrous cycle of different treatment groups of albino rat.

\begin{tabular}{|c|c|c|c|}
\hline Days & $\begin{array}{l}\text { Group I } \\
\text { (Letrozole+Natural recovery) }\end{array}$ & $\begin{array}{l}\text { Group II } \\
\text { (Letrozole+Plant drug treatment) }\end{array}$ & Group III (control) \\
\hline 1 & Diestrous & Metaestrous & Estrous \\
\hline 2 & Diestrous & Metaestrous & Estrous \\
\hline 3 & Diestrous-Proestrous & Metaestrous & Estrous \\
\hline 4 & Early Proestrous & Metaestrous & Metaestrous \\
\hline 5 & Proestrous & Metaestrous & Metaestrous \\
\hline 6 & Proestrous & Metaestrous & Diestrous \\
\hline 7 & Proestrous & Metaestrous -Diestrous & Diestrous \\
\hline 8 & Proestrous & Metaestrous-Diestrous & Diestrous \\
\hline 9 & Metaestrous & Metaestrous & Proestrous \\
\hline 10 & Metaestrous & Metaestrous & Proestrous \\
\hline 11 & Metaestrous -Diestrous & Metaestrous & Estrous \\
\hline 12 & Metaestrous -Diestrous & Metaestrous & Estrous \\
\hline 13 & Metaestrous -Diestrous & Metaestrous & Metaestrous \\
\hline 14 & Metaestrous & Metaestrous & Metaestrous \\
\hline 15 & Diestrous & Metaestrous & Diestrous \\
\hline 16 & Diestrous & Diestrous & Diestrous \\
\hline 17 & Diestrous & Diestrous & Diestrous \\
\hline 18 & Diestrous & Diestrous -Proestrous & Proestrous \\
\hline 19 & Diestrous & Metaestrous & Proestrous \\
\hline 20 & Diestrous & Metaestrous & Estrous \\
\hline 21 & Diestrous-Proestrous & Metaestrous & Estrous \\
\hline 22 & Diestrous -Proestrous & Metaestrous & Metaestrous \\
\hline 23 & Diestrous -Proestrous & Metaestrous & Metaestrous \\
\hline 24 & Proestrous & Metaestrous & Diestrous \\
\hline 25 & Proestrous & Metaestrous & Diestrous \\
\hline 26 & Proestrous & Metaestrous-Diestrous & Diestrous \\
\hline 27 & Metaestrous & Metaestrous-Diestrous & Proestrous \\
\hline 28 & Metaestrous & Metaestrous-Diestrous & Proestrous \\
\hline
\end{tabular}

\section{MATERIALS AND METHODS}

Collection of plant material: Tephrosia purpurea (Linn.) Pers. was collected from Barta mountain of Aswali region, Bordi, Maharashtra, India and was authenticated by blatter Herbarium, St Xavier's College, Mumbai, India. After collection the seeds were dried under room temperature to maintain its active principle and secondary metabolites present in it. Seeds were ground using mixer grinder; these powdered seeds were stored in air tight container. Dried seed powder of plant was used for experimental purpose and was given with milk using force feeding needle.

Experimental design: Animal model, female Albino wistar rats weighing $150-200 \mathrm{gm}$ body weight were
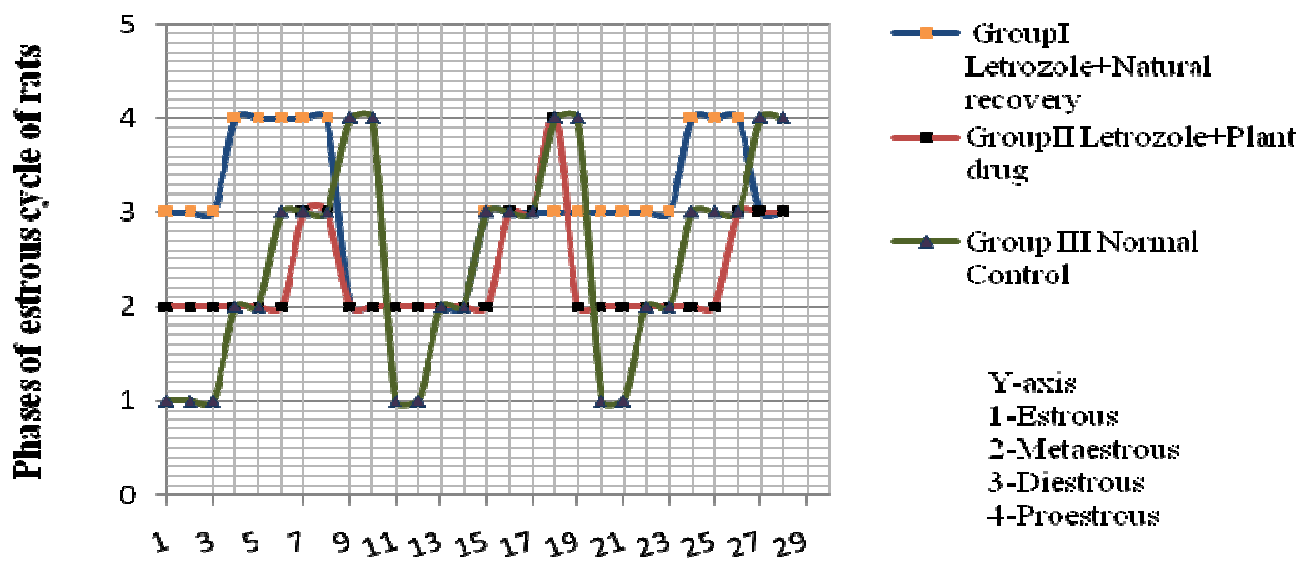

Number of treatment days

Fig.1. Phases of estrous cycle in female albino rats at different days of treatment. 
Table 2. Comparison of estrous cycle of Group I and Group II.

\begin{tabular}{|c|c|c|}
\hline Days & Group I & Group II \\
\hline 29 & Metaestrous & Diestrous \\
\hline 30 & Metaestrous & Diestrous \\
\hline 31 & Metaestrous & Proestrous \\
\hline 32 & Metaestrous & Proestrous \\
\hline 33 & Diestrous & Estrous \\
\hline 34 & Diestrous & Metaestrous \\
\hline 35 & Diestrous & Diestrous \\
\hline 36 & Diestrous & Diestrous \\
\hline 37 & Diestrous & Diestrous \\
\hline 38 & Proestrous & Proestrous \\
\hline 39 & Proestrous & Estrous \\
\hline 40 & Proestrous & Metaestrous \\
\hline 41 & Metaestrous & Metaestrous \\
\hline 42 & Metaestrous & Diestrous \\
\hline 43 & Metaestrous & Diestrous \\
\hline 44 & Diestrous & Diestrous \\
\hline 45 & Diestrous & Proestrous \\
\hline 46 & Diestrous & Estrous \\
\hline 47 & Proestrous & Metaestrous \\
\hline 48 & Proestrous & Metaestrous \\
\hline 49 & Estrous & Diestrous \\
\hline 50 & Metaestrous & Diestrous \\
\hline 51 & Metaestrous & Diestrous \\
\hline 52 & Metaestrous & Proestrous \\
\hline 53 & Diestrous & Estrous \\
\hline 54 & Diestrous & Metaestrous \\
\hline 55 & Diestrous & Metaestrous \\
\hline 56 & Proestrous & Diestrous \\
\hline 57 & Proestrous & Diestrous \\
\hline 58 & Estrous & Diestrous \\
\hline 59 & Metaestrous & Proestrous \\
\hline 60 & Metaestrous & Estrous \\
\hline 61 & Diestrous & Metaestrous \\
\hline 62 & Diestrous & Metaestrous \\
\hline 63 & Proestrous & Diestrous \\
\hline 64 & Estrous & Diestrous \\
\hline 65 & Metaestrous & Diestrous \\
\hline 67 & Metaestrous & Proestrous \\
\hline 68 & Diestrous & Estrous \\
\hline 69 & Diestrous & Metaestrous \\
\hline 70 & Diestrous & Metaestrous \\
\hline 71 & Proestrous & Diestrous \\
\hline
\end{tabular}

purchased from Haffkins Institute, Mumbai, India. Maintained at N.B. Mehta Science College, Bordi. The animals were kept in polypropylene cage with rice husk bedding and provided standard pellet diet and water ad libitum and maintained under normal condition. The rats were divided into 3 groups. Group I and II contained 15 rats per group and group III contained 4 rats and named as group I- letrozole followed by natural recovery, group II- letrozole +Plant drug and group III was considered as control. All rats were acclimatized for 14 days to laboratory conditions before commencement of experiment. Group I and II rats were administrated $1 \mathrm{mg} / \mathrm{kg}$ body weight Letrozole with $1 \% \mathrm{CMC} 2 \mathrm{mg} / \mathrm{kg}$ body weight and group III rats were given $1 \%$ CMC (Carboxymethyl cellulose) for 28 days (Kafali et al., 2004). During this period vaginal smears were collected daily for estrous cycle determination. On the day subsequent to last dose of letrozole administration, 3 rats of group I and 4 rats of group III were sacrificed for evaluation of reproductive system weight and hormonal level. Group I there were 15 animals, 12 were kept for natural recovery, and examining their estrous cycle. Out of 12,3 rats were sacrificed at interval of 15 days for further evaluating whether PCOS reverts naturally up to 71days. The remaining 3 were kept for mating to check its fertility. In group II, there were 15 animals, after induction of PCOS by letrozole rats were treated with plant drug i.e. seed powder of $T$. purpurea $0.2 \mathrm{gm} / \mathrm{kg}$ body weight with milk $3 \mathrm{ml} / \mathrm{kg}$ body weight from $29^{\text {th }}$ day onwards for at least 3 consecutive estrous cycles (i.e. up to $43^{\text {rd }}$ day). During this period vaginal smear were collected daily for estrous cycle determination. On the day subsequent to last dose of plant drug $T$. purpurea 3 rats were sacrificed for further evaluation and out of 12, 3 rats were sacrificed at interval of 15 days for evaluating their percentage of normalcy in hormonal level up to 71 days. Remaining 6 rats were kept for mating.

For biochemical analysis food was discontinued 12-15 hours prior to sacrifice for each group,but water was provided ad libitum Animal were sacrificed as per the experimental design, with overdose of ether. The blood sample was collected by puncture, in preheparinised eppendrof tubes using preheparinised syringes. The eppendrof were centrifuged at $4000 \mathrm{rpm}$ and plasma was separated. This plasma was used for estimation of hormonal essay.

Plasma Testosterone, LH and FSH were estimated by competitive chemiluminescent immunoassay using automated instrument ADIVA Centaur, Bayer Diagnostic Europe Limited for TSTO, LH and FSH kit respectively (Yilmaz et al., 2001). Plasma Estrogen was estimated by chemiluminescent micro particle immunoassay using E2-kit (Taieb et al., 2007).

\section{RESULTS AND DISCUSSION}

After induction of PCOS with letrozole (Group I and II), rats showed irregularity in their estrous cycle, compared to normal rats (Group III control) when studied up to $29^{\text {th }}$ day (Table 1, Fig. I). Letrozole treated PCOS induced rats (Group I) showed irregularity in its estrous cycle compared to (group II), when allowed for natural recovery (Table 2, Fig. 2) T. purpurea treated PCOS induced rats (Group II) showed reduced ovary and reproductive system weight (Table 3) and decrease level of hormone testosterone and estrogen (Table 4), when compared with control (Group III ) and naturally recovered rats (Group I).Similar findings were obtained for testosterone and ovary weight using Mimosa pudica (Jadhav et al., 
Table 3. Ovary and reproductive system weight of female albino rat. (Average of three replicates).

\begin{tabular}{lccc}
\hline Parameters & Group I & Group II & Group III \\
\hline Ovary weight/body $(\mathrm{gm})$ & $0.49 \mathrm{gm}$ & $0.38 \mathrm{gm}$ & $0.45 \mathrm{gm}$ \\
Weight of female reproductive system/body $(\mathrm{gm})$ & $2.233 \mathrm{gm}$ & $1.631 \mathrm{gm}$ & $1.807 \mathrm{gm}$ \\
Total no of matured follicles & 1 & 1 & 5 \\
\hline
\end{tabular}

Table 4. Hormonal level of different treatment groups of female albino rat.

\begin{tabular}{|c|c|c|c|c|}
\hline Day & parameters & $\begin{array}{c}\text { Group I (15rats) } \\
\text { Letrozole + Natural } \\
\text { Recovery }\end{array}$ & $\begin{array}{c}\text { Group II(15rats) } \\
\text { Letrozole + Plant } \\
\text { drug treatment }\end{array}$ & $\begin{array}{l}\text { Group III(4rats) } \\
\text { Normal Control }\end{array}$ \\
\hline \multirow[t]{4}{*}{$29^{\text {th }}$} & Testosterone(ng/dl) & $253.55 \pm 4.04$ & - & $38.07 \pm 1.16$ \\
\hline & Estrogen $(\mathrm{pg} / \mathrm{ml})$ & $1297.88 \pm 1.16$ & - & $110.21 \pm 1.01$ \\
\hline & $\mathrm{FSH}(\mathrm{mlU} / \mathrm{ml})$ & $>0.3$ & $>0.3$ & $>0.3$ \\
\hline & $\mathrm{LH}(\mathrm{mlU} / \mathrm{ml})$ & $>0.07$ & $>0.07$ & $>0.07$ \\
\hline \multirow[t]{2}{*}{$43^{\text {rd }}$} & Testosterone(ng/dl) & $180.03 \pm 1.57$ & $140.05 \pm 0.55$ & - \\
\hline & Estrogen $(\mathrm{pg} / \mathrm{ml})$ & $627.57 \pm 4.91$ & $325.07 \pm 5.33$ & - \\
\hline \multirow[t]{2}{*}{$57^{\text {th }}$} & Testosterone(ng/dl) & $160.45 \pm 5.77$ & $129.08 \pm 0.95$ & - \\
\hline & Estrogen $(\mathrm{pg} / \mathrm{ml})$ & $431.65 \pm 6.79$ & $297.21 \pm 1.16$ & - \\
\hline \multirow[t]{2}{*}{$71^{\mathrm{st}}$} & Testosterone(ng/dl) & $147.33 \pm 2.07$ & $97.07 \pm 0.92$ & - \\
\hline & Estrogen $(\mathrm{pg} / \mathrm{ml})$ & $398.07 \pm 1.01$ & $255.77 \pm 0.70$ & - \\
\hline
\end{tabular}

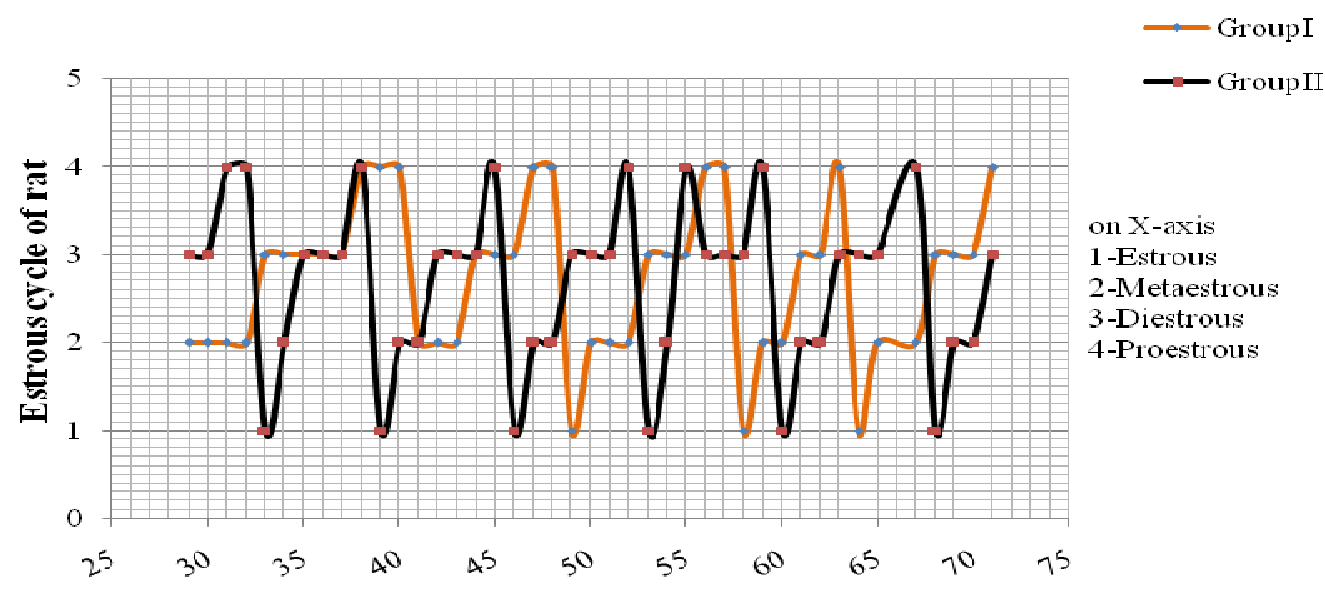

Number of treatment days

Fig.2. Estrous cycle in female albino rat at different days of treatment.

2013). Hormone LH and FSH did not show any drastic changes after plant drug treatment as compared to letrozole treated rats (Table 4) probably because these hormones are secreted from pituitary gland and plant which was used targeted on ovarian hormones. After completing treatment female rats kept with male rats for mating and pregnancy was confirmed.

\section{Conclusion}

The seeds of $T$. purpurea had potential effect on PCOS bringing the reproductive cycle of the rats to normalcy. It was concluded that the estrous cycle of the rats was disturbed when they were in polycystic ovary condition. The irregular cycles were preceded by persistent vaginal cornification (PVC). The estrous cycle restored to $80 \%$ normalcy in the animals treated with the seed powder of $T$. purpurea. Letrozole also led to increase production of testosterone which improved after the plant drug treatment.

\section{ACKNOWLEDGEMENT}

The authors are thankful to the Principal of N.B. Mehta science college, Bordi for providing laboratory for experimental purpose.

\section{REFERENCES}

Craig, W.J. (1999). Health Promoting Properties of common herb. A.M.J Clin. Nutr., 70: 491-499.

Deshpande, S.S., Shah, G.B. and Parmar, N.S. (1968). Antiulcer activity of Tephrosia purpurea in rats. Indian. J Pharmacol Biochem.Biophy,110: 119-130.

Fallon, L.F. (2006). Polycystic ovary syndrome. Gale encyclopedia of medicine. Third Edition. Jacqueline L. Longe, Editor. Farmington Hills, MI. Thomson Gale. 
Hans, Peter. W., Deute, M. and Imilda, E. (2000). Chemoprevention of tobacco smoke induced lung carcinogenesis in mice. Carcinogenesis, 21: 977-982.

Jadhav M, Menon S. and Shailajanet S. (2013). In vivo evaluation of Mimosa pudica Linn. In the management of Polycystic ovary using rat model. International Journal of applied biology and pharmaceutical Tech, 4 (1):285-292.

Janssen, O.E., Mehlmauer, N., Hahn, S., Offner, A..H. and Gartner, R. (2004). High prevalence of autoimmune thyrodities in patient with polycystic ovary syndrome. European journal of Encyclopedia, 150 (3): 363-369

Joshi, S.G. and Oleacea, I.N. (2000). Medicinal plants .New Delhi: Oxford and IBH publishing Co-Pvt Ltd pp 211.

Kafali, H., Iriadam, M., Ozardali, I. and Demir, N. (2004). Letrozole induced polycystic ovaries in the rat: A new model for Cystic ovarian diseases. Archives of medical research, official journal of intituto Maxiccano Del Seguro Social, 35 (2) :103-108.

Khare, P. (2004). Encyclopedia of Indian Medicinal Plants. Springer-verlag Berllin Heidel Berg, Newyork.

Nadkarni, A.K. (1982). Indian Meteria Medica. Popular Prakashan, Private limited, Bombay Vol-3(1): 561-562

Pandey, S.N, Singh, M. P. and Srivastava, J. L. (2003).
Indiginous medicinal plants, social forestry and Tribal. First edition Daya publishing house, Delhi.

Saleem, M., Ahemed, S. and Sultana, S. (1999). Tephrosia Purpurea alleviates phorbol ester tumor promotion responses in murine skin. Pharmacol comm.,5: 455-461.

Shearman, R.P. (1985).Clinical reproductive endocrinology.Churchill Livingstone, Inc, New York, 523-533.

Speroff, L., Glass, R.H. and Kase, N.G. (1999). Clinical Endocrinology. Willams and Wilkins, USA, 6:529-556

Taieb, J., Mendez, D. H., Benatter C. and Pous, C. (2007). Enlightenment about the new Architect-i2000 estradiol (Abbott Laboratories) immunoassay during in vitro fertilization. Clin. Biochem, 40(18):1423-1426.

Yilmaz, B., Kutlu, S., Canpolat, S., Sandal S., Ayar A., Mogulkoc, R. and Kelestimur, H. (2001). Effect of paint thinner exposure on serum LH, FSH and Testosterone levels and hypothalamic catecholamine content in the male rats. Bio. Pharma Bull, , 24(2):163-166.

Zarger, A.H., Gupta,V.K., Wani, A.I., Masoodi, S.R., Bashir, M.I., Laway, B.A., Ganie, M.A.S. and Salahuddin, M. (2005). Prevalence of ultra sonography proved polycystic ovaries in North Indian Women with type 2 Diabetes Mellitus. Reproductive Biology and Endocrinology,35 (3). 